\title{
The impact of leadership style on employee motivation in the automotive industry: A British perspective
}

\author{
Nadezhda Angelova Vasileva \\ Bucks New University, UK \\ Palto Datta \\ Regent College, UK
}

\begin{abstract}
Keywords
Leadership styles, employee motivation, autocratic leadership, democratic, laissez-faire, situational leadership, transformational and charismatic leadership style, automobile industry
\end{abstract}

\begin{abstract}
Purpose: The effectiveness of leadership is critical at all levels of the organisation. Different organisations use a variety of leadership styles and methods to improve employee performance by inspiring them and providing them with adequate opportunities. The research purpose is to examine the impact of leadership styles on employee's motivation in the automotive industry in the United Kingdom.

Methodology: The researchers used a deductive approach in conjunction with the quantitative method to determine the study's outcomes. A sample of 100 people was used for primary data using a questionnairebased survey. Subjects are from the automotive industry, and the survey was carried out online.

Findings: According to the results, Democratic Leadership Style (DLS), Autocratic Leadership Style (ALS), Laissez-faire Leadership Style (LFLS), Situational Leadership Style (SLS), Transformational Leadership Style (TLS), and Charismatic Leadership Style (CLS) are among the six study variables that are highly significant in terms of employee motivation. Autocratic Leadership Style (ALS) and Charismatic Leadership Style (CLS) were determined to be the study's less significant variables (CLS). The findings suggest that there is a positive relationship between leadership styles and employee motivation.

Conclusion and study implications: The findings of this study can be used to develop strategies and achieve goals by developing and implementing a good leadership style. Transformational leadership is important, and leaders and managers should strive to demonstrate it in their daily activities. This study's findings have both academic and commercial implications. Leaders should use suitable styles and an inclusive and equitable incentive scheme to motivate employees by setting expectations.
\end{abstract}

Corresponding author: Nadezhda Angelova Vasileva

Email addresses for the corresponding author: nadiavasileva.6@gmail.com

The first submission received: $14^{\text {th }}$ June 2021

Revised submission received: $15^{\text {th }}$ October 2021

Accepted: 29th October 2021

\section{Introduction and background}

Nowadays, organisations and the growth and survival of a community are critical for an individual's daily performance and job function. Organisations were founded to address social issues and engage in communal activity. Human beings primarily drive organisations. They commit their entire time to organisations and assist them in achieving their goals. As a result, without management, human development, and efforts and the outcomes of these efforts, achieving the objectives is not achievable. Given that the presence of humans is the core concept of the organisation, the most fundamental action that must be performed to accomplish this is to retain employees and assure their psychological and professional fulfilment throughout their employment (Mullins, 2007).

Throughout human history, whenever a person has functioned as a leader, the expansions and variations brought about by people and organisations have been attributed to that person's leadership. Historically held leadership is a vital component of the foundations of human civilisations, and it is also a critical component of effective management. It becomes evident when seen as a function. Each business requires strong leadership to achieve its objectives. Because effective leadership is a vital component of 
enhancing a company's performance, a company's success or failure is defined by the effectiveness of leadership at all levels of the organisation. Shirzad, Kebriya, and Zanganeh (2011) discovered that leadership consists of the beliefs, attitudes, and talents to influence others to fulfil company objectives. As a result, performance will impact staff morale (Shirzad, Kebriya and Zanganeh, 2011).

Leadership effectiveness is crucial at all levels of the organisation (Duckett and Macfarlane,2003). Leadership is vital for all organisations because it is critical for improving their overall performance to fulfil objectives. To manage colleagues well, the manager must possess the essential abilities and tactics and increase employee motivation and job happiness. Given that people constitute an organisation's engine, this can significantly boost the organisation's performance (Yukl, 2001). An organisation's leadership style significantly impacts its employees' level of engagement and dedication (Obiruwu, 2011). To increase employee motivation and inspire employees to contribute to company goals, it is also vital to encourage them (Chi, Lan, and Dorjgotov, 2012). Managers should employ a variety of leadership and management styles to maximise efficiency, which needs diverse leadership techniques for the powerful symbol in achieving departmental objectives. Similarly, commitment to the organisation and performance are inextricably tied to leadership style (Hueryren Yeh 2012).

This research aims to look into the effect of leadership styles on employee motivation in the automotive industry context. Key objectives are:

1. To define the concept of leadership style and the various leadership styles used in the automotive industry.

2. To assess the importance of employee motivation and its impact on organisational performance.

3. To evaluate the relationship between leadership style and employee motivation.

\section{Literature Review}

\subsection{Leadership: key concepts}

Many previous researchers have used the term "leader" to refer to someone in command of a group of people (Yukl 2001, Musinguzi et al. 2018)). In certain circumstances, a person can be a leader if he can influence and remain essential to his partner to achieve the organisation's primary goal. According to Yulk (2001), the cliques may include the leader's close relatives or friends, as well as the leader's subordinates. To become a leader, you must first gather a group of followers eager to follow you. People will follow anyone who can provide them with the resources they require to realise their dreams and desires. A leader has authority over their cliques or coworkers, allowing them to influence their behaviour. As a result, leaders have power and influence over others, respect their followers, and contribute to the group's and organisation's goals (Nwachukwul, 2007). According to Bernis (2009), a leader has authority over individuals who have the power to impose their views and behaviours on others or those who follow them.

Prentice (2004) asserted that leadership is associated with achieving organisational goals by managing and structuring their cliques, colleagues, and associates' resources to achieve a common goal. Other experts defined leadership as an attempt to lead or direct the formation of clubs and the completion of a specific undertaking for the common good (Fiedler, 2009; Zenger and Folkman, 2002). According to Smylie et al. (2005), leadership is exercised by a person who has defined tasks and task-oriented ideas and acts as a critical "function" in relationships with other leaders, followers, and situations.

\subsection{Leadership Styles \\ Autocratic leadership style}

Certain researchers use authoritarian leadership to describe autocratic leadership Zenger and Folkman, 2002; Smylie et al., 2005). Autocratic leaders wield enormous power and influence to manipulate others. Because they have authority over their followers, authoritarian leaders provide specific and concise instructions for completing tasks. As a result, assuming that autocratic leadership is used in negative leadership is not always correct (Dyczkowska and Dyczkowski, 2018). Most medium and small businesses employ this leadership style (Pellegrini and Scandura, 2008). Authoritarian leadership never allows workers to make decisions and keeps a distance from followers. They believe that to be a leader in person or a group, and one must keep a distance from the individuals (Egwunyenga, 2010). Many academics believe that most totalitarian regimes do not pay enough attention to socio-emotional aspects of 
organisations, such as group cohesion and the promotion of cohesiveness as a fundamental component in social life cycles (Yukl, 2014).

\section{Democratic leadership style}

Employees are considered when making decisions in this leadership style. Igbaekemen and Odivwri (2015) are known for their bravery, intellect, fairness, competence, inventiveness, and honesty, as well as their largely positive democratic leadership. Leaders with this personality type offer options and assistance to their followers. Democratic leadership, also known as participatory leadership, stands for, as the name implies, fair participation, inclusion, and self-determination; however, it is not to be confused with individuals who hold elected positions of power (Igbaekemen and Odivwri, 2015). Accountability, active participation, collaboration, and delegation of duties and responsibilities are how democratic leaders establish authority. The democratic leadership's duties within the organisation include distributing responsibilities and fostering group debates. Accepting personal responsibility for the organisation, accountability for their choices, wanting to preserve their collective's self-determination and independence, taking on the role of leader when required or appropriate, and cooperating with leaders are all responsibilities of democratic followers (McShane et al., 2009).

\section{Leaders with a laissez-faire attitude}

According to Luthans (2011), laissez-faire leadership is defined as the abdication of responsibilities and the refusal to participate in the motivational process. On the other hand, Robbins and Judge (2013) agree with Luthans (2011) and reach the same conclusion. Laissez-faire leaders are uninterested in the efforts of their followers and coworkers. Leaders who employ a laissez-faire leadership style are frequently regarded as passive. Their attribution has a negative impact on their followers' performance (Judge and Piccolo, 2004). Laissez-faire leadership styles appear to be a passive type of leadership, according to Hinkin and Schriesheim (2008), who agree with the previous point. People with this leadership characteristic are more likely to keep their followers at a social distance. Businesses suffer because of this long-distance relationship between leaders and followers. When you consider that they will be avoiding the followers, they will be less likely to be confronted with company requirements and management goals than they should be, limiting the possibility of a company operating at total capacity. According to Hinkin and Schriesheim (2008), laissez-faire leadership is characterised by a "lack of leadership."

On the other hand, Wong and Giessner (2016) believe that this type of leadership is advantageous. The effectiveness of their actions is determined by their followers' assessment of their leadership qualities. Even though some leadership literature considers laissez-faire leadership a lousy leadership style, there may be a follower who thrives and is drawn to it (Hinkin and Schriesheim, 2008). Certain followers may view increased responsibilities and decision-making authority as part of being empowered. They see all their responsibilities and autonomy as opportunities to improve themselves by exceeding their superiors' expectations. According to Chaudhury and Javed (2012), laissez-faire leadership can benefit an organisation when leaders and followers are both equally motivated and knowledgeable in their fields.

\section{Situational Leadership Style}

Although behavioural theories have helped propose and express potential leadership styles, they have failed to guide what constitutes effective leadership in various situations (Bolden, 2004). Some scholars believe that no single leadership style is all-encompassing or appropriate for every manager in every case or circumstance. As a result, situational theories were developed to demonstrate that the appropriate style is heavily influenced by the circumstances, personnel, task at hand, organisation, and other external factors. According to Fielder (2009), there is no such thing as a one-size-fits-all leadership strategy; instead, a thorough examination of the situation should be used to determine the leadership style. Fielder (2009) went on to differentiate between task-oriented managers and those who prioritise interpersonal relationships. Job-oriented managers, he claims, are more focused on the task at hand and perform better in situations where there is already a structure in place that promotes camaraderie or team spirit, defined duties, and either solid or weak leadership styles.

Managers who prioritise relationships outperform others and have a more participative leadership style. Furthermore, they are thought to perform admirably when the job is unstructured. Still, they hold a 
high position of power and when the figurehead relationships fluctuate between good and bad, and the job is unstructured. Such leaders appear to be more directive in their leadership style.

\section{Transformational Leadership Style}

The term "transformational leadership" refers to leadership that affects both people and their social systems. As a result of these tactics, likely changes in followers occur, resulting in a future leader (Kendrick, 2011). Furthermore, transformative leadership appeals to workers' moral principles. This will eventually raise awareness and mobilise the energy of followers to transform institutions (Yukl, 2014). Transformational leaders inspire followers to feel trust, affection, loyalty, and admiration for them. Transformational leaders inspire their followers to go above and beyond what is expected of them. According to Yukl (2014), leaders influence followers in three ways: first, by increasing their understanding of the importance of job outcomes; second, by persuading people to put their interests aside for the good of the team or organisation; and third, by activating higher-order needs.

\section{Charismatic Leadership Styles}

In times of societal crisis, a leader's charisma is typically demonstrated when they rise with bold ideas and offer imaginative solutions to their followers. Charisma is fuelled by a set of personality traits that only leaders have, and the average person does not. According to Conger et al. (2009), charisma is a distinct personality trait that leads to charismatic leadership. However, both the followers' and the leader's distinguishing characteristics can have an impact on a leader's charismatic characteristics. Willner (2008) discovered that charismatic leadership is determined by perception rather than personality or environment. Simply put, it all comes down to how followers perceive their leader, not what the leader does to foster the charismatic bond. Willner (2008) went on to say that two factors influence the development of charisma in leaders and followers. It all comes down to the connection. Employee

\subsection{Motivation}

Over the last two decades, leadership and motivation appear to be two business themes that have gotten a lot of attention (Schaffer, 2008). "motivation" is commonly used to define leadership (Orozi Sougui et al., 2017). For attaining corporate goals, enthusiasm is a powerful motivator. As a result, it's plausible to assume that addressing individual needs can lead to personal excitement Haque, Haque, and Islam (2014). They also claimed that motivation requires addressing employee demands while simultaneously accomplishing organisational goals. Motivation is a process by which people participate in voluntary actions in the desired direction and stick to their goals and priorities (Ramlall, 2004). Motivation levels vary from person to person, and even within the same person, motivation levels might behave differently depending on the situation (Judge and Robbins,2013). As a result, they propose a three-part synergy for motivation. These are a person's abilities, tendencies, and persistence in completing goals. When we look at these three characteristics individually, we can see that none of them can stand alone without the help of others. When it comes to intensity, unless the force is channelled in a specific way, a high degree of power is unlikely to result in solid work performance. Then there's the issue of perseverance, which influences how long someone can labour. Motivated employees will work if it takes to attain their objectives.

Maslow's (1954) Hierarchy of Needs is one of the most well-known motivational variables in the world, according to Haque, Haque, and Islam (2014). According to Maslow's theory, "people continually seek something, and what they genuinely want depends on what they already have." Maslow categorised human needs into five categories: physiological, safety, love/belonging, esteem, and self-actualisation. Maslow has organised these five criteria into layers from bottom to top: Workers' basic needs are at the bottom of the triangle. Addressing each of the bottom levels means the employee will be promoted to the next layer. Douglas McGregor (1960) was the first to propose the incentive theories X and Y. He identified two distinct forms of human nature. Managers believe that certain employees have a natural dislike of work and that monitoring and managing them in the workplace is crucial to the organisation's performance, according to Theory $X$. Apart from hypothesis $Y$, ordinary people are willing to accept and even desire duties because they consider labour as a form of enjoyment and relaxation in the life of an organism. 
Frederick Herzberg's (1966) Two Factor Motivation Theory is another motivation-related theory that was introduced in the late 1960s. According to Robbins and Judge (2013), everyone's attitude toward work is equal, and one's attitude toward work can determine whether one succeeds or fails. As a result, Psychologist Herzberg asked people to describe how they felt about their jobs in a specific scenario. Based on the responses, he developed the Two-Factor Theory. There are two requirements in this concept: motivational reasons and hygienic aspects. According to Herzberg's research, the antithesis of contentment is not unhappiness, as previously supposed (Robbins and Judge, 2013). Eliminating unsatisfactory features will not result in job satisfaction. It will just cause you to be dissatisfied.

\section{Research Methodology}

To carry out the research using quantitative research methodology, a positivistic research philosophy and a deductive approach are used. Secondary research is carried out by examining current and relevant literature to comprehend the concept of leadership, various leadership styles, and critical attributes. The quantitative analysis is based on the survey data. Data collection methods are essential for conducting successful research because they enable researchers to collect data from various reliable sources. Clark and Vealé (2018) portray data collection techniques as an essential stage in completing research activity. To complete the study task effectively, researchers conducted both primary and secondary research.

A questionnaire-based survey with a sample size of 100 is used to collect data, and a simple random sample is used. Because of the current Covid-19 restrictions, data is collected via an online platform. Researchers collect data on study subjects using a Likert 5 scale. It aids researchers in gathering data on respondents' responses based on five criteria (Ebert et al., 2018). A Likert scale is a type of quantitative data that enables researchers to estimate distances between various locations (Tjora, 2018).

\section{Findings}

\subsection{Demographics}

Table 1: Age and Gender of the Participants

\begin{tabular}{|c|c|c|c|c|c|c|}
\hline \multicolumn{7}{|c|}{ Your Gender: } \\
\hline & & \multicolumn{2}{|c|}{ Frequency } & Percent & Valid Percent & Cumulative Percent \\
\hline \multirow[t]{3}{*}{ Valid } & Male & \multicolumn{2}{|l|}{46} & 46.0 & 46.0 & 46.0 \\
\hline & Female & \multicolumn{2}{|l|}{54} & 54.0 & 54.0 & 100.0 \\
\hline & Total & \multicolumn{2}{|c|}{100} & 100.0 & 100.0 & \\
\hline \multicolumn{7}{|c|}{ Your Age: } \\
\hline & & & Frequency & Percent & Valid Percent & Cumulative Percent \\
\hline \multirow[t]{6}{*}{ Valid } & \multicolumn{2}{|l|}{29 and below } & 15 & 15.0 & 15.0 & 15.0 \\
\hline & 30 to 39 & & 20 & 20.0 & 20.0 & 35.0 \\
\hline & 40 to 49 & & 25 & 25.0 & 25.0 & 60.0 \\
\hline & 50 to 59 & & 20 & 20.0 & 20.0 & 80.0 \\
\hline & 60 and above & & 20 & 20.0 & 20.0 & 100.0 \\
\hline & Total & & 100 & 100.0 & 100.0 & \\
\hline
\end{tabular}

According to the survey findings, the researchers discovered nearly equal participation of male and female participants in the survey, where people of various ages participated.

\subsection{Reliability Test}

The reliability analysis was performed to check the internal consistency of the participant responses, and the researcher used the Cronbach's Alpha method to test the internal consistency.

Table 2: Reliability Statistics

\begin{tabular}{|l|l|}
\hline \multicolumn{2}{|c|}{ Reliability Statistics } \\
\hline Cronbach's Alpha & N of Items \\
\hline .972 & 18 \\
\hline
\end{tabular}

The Alpha test results show an Alpha value of 0.972, more significant than the required value of 0.50 , indicating that the data collected for this study is internally consistent. 


\subsection{Leadership Styles}

In terms of the autocratic leadership style, most of the participants agreed with the statements. Three statements were asked, and the results indicate that autocratic leaders use their great authority and power to exert control over others, authoritarian leaders wield authority over their followers, they give precise and concise instructions for completing duties, and authoritarian leadership never allows workers to make choices and keeps a distance from followers. In terms of the Democratic Leadership Style, most of the participants agreed with the assertions. Employees are considered when making decisions in a democratic leadership style; democratic leadership represents equitable involvement, inclusion, and selfdetermination, as the name implies, and democratic leadership practises are much more motivating than the other styles.

\begin{tabular}{|l|r|r|r|}
\hline \multicolumn{4}{|c|}{ Statistics } \\
\hline & \multicolumn{1}{|c|}{ ALS1 } & \multicolumn{1}{|c|}{ ALS 2 } & \multicolumn{1}{c|}{ ALS3 } \\
\hline Mean & 3.62 & 3.80 & 3.86 \\
\hline Median & 4.00 & 4.00 & 4.00 \\
\hline Mode & 4 & 4 & $4^{3}$ \\
\hline Std. Deviation & 1.144 & 1.092 & 1.247 \\
\hline Sum & 362 & 380 & 386 \\
\hline a. Muttiple modes exist. The smallest value is shown \\
\hline
\end{tabular}

Table-3: Autocratic leadership style

\begin{tabular}{|l|r|r|r|}
\hline \multicolumn{4}{|c|}{ Statistics } \\
\hline & \multicolumn{1}{|c|}{ DLS1 } & \multicolumn{1}{|c|}{ DLS2 } & \multicolumn{1}{c|}{ DLS3 } \\
\hline Mean & 3.73 & 3.53 & 3.62 \\
\hline Median & 4.00 & 4.00 & 4.00 \\
\hline Mode & $4^{\mathrm{a}}$ & 4 & 4 \\
\hline Std. Deviation & 1.230 & 1.218 & 1.144 \\
\hline Sum & 373 & 353 & 362 \\
\hline a. Multiple modes exist. The smallest value is shown \\
\hline
\end{tabular}

Table-4: Democratic leadership style

In terms of the Laissez-faire Leadership Style, most of the participants in this study agreed with the claims. According to the findings, laissez-faire leadership is an abandonment of duties and a refusal to participate in the motivational process. Laissez-faire leaders are uninvolved in the work of their followers and coworkers, and laissez-faire leadership styles appear to be a passive type of leadership. Regarding the Situational Leadership Style, it was discovered that most of the participants in this study agreed with the statements, with the second most strongly agreeing with the statements. It was found in this section that situational theories of leadership were developed to demonstrate that the conditions strongly influence the appropriate style; the situational leadership style is the leadership style that should be chosen after a thorough analysis of the situation; and using the situational leadership style, the leaders are used to make decisions based on the situation arrived.

\begin{tabular}{|l|r|r|r|}
\hline \multicolumn{4}{|c|}{ Statistics } \\
\hline & \multicolumn{1}{|c|}{ LFLS1 } & \multicolumn{1}{|c|}{ LFLS2 } & \multicolumn{1}{c|}{ LFLS3 } \\
\hline Mean & 3.73 & 3.84 & 3.80 \\
\hline Median & 4.00 & 4.00 & 4.00 \\
\hline Mode & 4 & 4 & 4 \\
\hline Std. Deviation & 1.136 & 1.126 & 1.092 \\
\hline Sum & 373 & 384 & 380 \\
\hline
\end{tabular}

Table-5: Laissez-faire Leadership Style

\begin{tabular}{|l|r|r|r|}
\hline \multicolumn{4}{|c|}{ Statistics } \\
\hline & \multicolumn{1}{|c|}{ SLS1 } & \multicolumn{1}{|c|}{ SLS2 } & \multicolumn{1}{c|}{ SLS3 } \\
\hline Mean & 3.75 & 3.64 & 3.65 \\
\hline Median & 4.00 & 4.00 & 4.00 \\
\hline Mode & 4 & 5 & 4 \\
\hline Std. Deviation & 1.048 & 1.259 & 1.114 \\
\hline Sum & 375 & 364 & 365 \\
\hline
\end{tabular}

Table-6: Situational Leadership Style

In terms of the Transformational Leadership Style, most participants agreed with the assertions, with the second most strongly agreeing. According to the findings, transformational leadership is a type of leadership that impacts people and their social systems; transformative leadership appeals to workers' moral principles, and transformational leaders inspire their people to go above and beyond what they expected. Charisma is fueled by a few behavioural characteristics that only leaders have and that the average person lacks, charisma is a characteristic that is distinctive to a person and results in charismatic leadership, and in times of societal crisis, a leader's charisma is often shown when he or she emerges with bold ideas and offers inventive answers to their followers. 


\begin{tabular}{|l|r|r|r|}
\hline \multicolumn{5}{|c|}{ Statistics } \\
\hline & \multicolumn{1}{|c|}{ TLS1 } & \multicolumn{1}{|c|}{ TLS2 } & \multicolumn{1}{c|}{ TLS3 } \\
\hline Mean & 3.62 & 3.78 & 3.86 \\
\hline Median & 4.00 & 4.00 & 4.00 \\
\hline Mode & 4 & 4 & $4^{\mathrm{3}}$ \\
\hline Std. Deviation & 1.144 & 1.079 & 1.247 \\
\hline Sum & 362 & 378 & 386 \\
\hline a. Muttiple modes exist. The smallest value is shown \\
\hline
\end{tabular}

Table-7: Transformational leadership style

\begin{tabular}{|l|r|r|r|}
\hline \multicolumn{4}{|c|}{ Statistics } \\
\hline & \multicolumn{1}{|c|}{ CLS1 } & \multicolumn{1}{c|}{ CLS2 } & \multicolumn{1}{c|}{ CLS3 } \\
\hline Mean & 3.73 & 3.53 & 3.57 \\
\hline Median & 4.00 & 4.00 & 4.00 \\
\hline Mode & $4^{3}$ & 4 & 4 \\
\hline Std. Deviation & 1.230 & 1.218 & 1.233 \\
\hline Sum & 373 & 353 & 357 \\
\hline a. Muttiple modes exist. The smallest value is shown & \\
\hline
\end{tabular}

Table-8: Charismatic leadership style

\subsection{Employee Motivation (EMTV)}

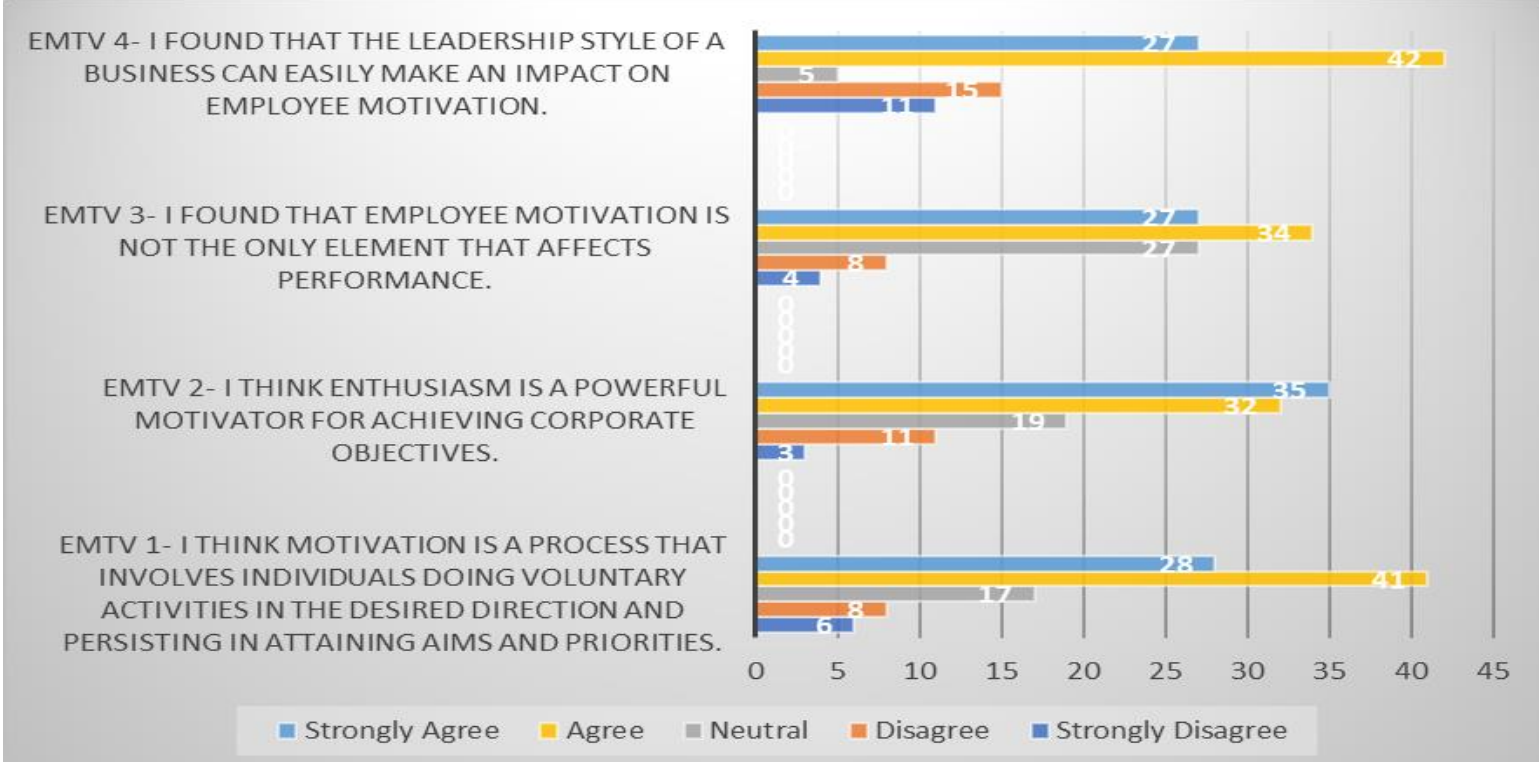

Figure 1: Employee Motivation (EMTV) Frequencies

Regarding Employee Motivation, it was discovered that most of the participants in this study agreed with the statements. The findings also show that female employees are more likely to agree in statements where the age group of 40 to 49 was positive in most cases. However, based on the analysis of the primary data, the respondents were optimistic about these variables. As a result of the survey findings, most employees in the UK automobile sector are satisfied and motivated by leadership style. According to the findings, motivation is a process that involves individuals performing voluntary activities in the desired direction and persisting in achieving goals and priorities. Enthusiasm is a powerful motivator for achieving corporate objectives. Employee motivation is not the only factor influencing performance, and a company's leadership style can easily influence employee motivation.

Table 3: Employee Motivation (EMTV) Statistics

\begin{tabular}{|l|r|r|r|r|}
\hline \multicolumn{5}{|c|}{ Statistics } \\
\hline & EMTV 1 & \multicolumn{1}{|c|}{ EMTV 2 } & \multicolumn{1}{c|}{ EMTV 3 } & \multicolumn{1}{c|}{ EMTV 4 } \\
\hline Mean & 3.77 & 3.85 & 3.72 & 3.59 \\
\hline Median & 4.00 & 4.00 & 4.00 & 4.00 \\
\hline Mode & 4 & 5 & 4 & 4 \\
\hline Std. Deviation & 1.127 & 1.114 & 1.074 & 1.326 \\
\hline Sum & 377 & 385 & 372 & 359 \\
\hline
\end{tabular}

The data analysis reveals that the participants had a significant reaction, with most responses being positive. The table shows that the mean value for each assertion is nearly 4 and the median value is 4 in every instance, indicating that the participants answered positively and agreed in most cases. The 
standard deviation number also indicates that the variables are evenly distributed in a low to medium range.

\subsection{Correlation}

The researcher used correlation and regression analysis to determine the relationship between different leadership styles and employee motivation. In the correlation analysis, employee motivation was used as the dependent variable, and leadership styles were used as the independent variables.

Table 4: Correlation Analysis

\begin{tabular}{|c|c|c|c|c|c|c|c|}
\hline \multicolumn{8}{|c|}{ Correlations } \\
\hline $\begin{array}{l}\text { Dependent } \\
\text { Variables }\end{array}$ & $\begin{array}{l}\text { Independent } \\
\text { Variables }\end{array}$ & $\begin{array}{l}\text { Section 1: } \\
\text { Autocratic } \\
\text { Leadership } \\
\text { Style } \\
\text { (ALS)- }\end{array}$ & $\begin{array}{l}\text { Section 2: } \\
\text { Democratic } \\
\text { Leadership } \\
\text { Style } \\
\text { (DLS)- }\end{array}$ & $\begin{array}{l}\text { Section 3: } \\
\text { Laissez-faire } \\
\text { Leadership } \\
\text { Style (LFLS)- }\end{array}$ & $\begin{array}{l}\text { Section 4: } \\
\text { Situational } \\
\text { Leadership } \\
\text { Style } \\
\text { (SLS)- }\end{array}$ & $\begin{array}{l}\text { Section 5: } \\
\text { Transformational } \\
\text { Leadership Style } \\
\text { (TLS)- }\end{array}$ & $\begin{array}{l}\text { Section 6: } \\
\text { Charismatic } \\
\text { Leadership } \\
\text { Style (CLS)- }\end{array}$ \\
\hline \multirow[t]{6}{*}{$\begin{array}{l}\text { Section 7: } \\
\text { Employee } \\
\text { Motivation } \\
\text { (EMTV)- }\end{array}$} & $\begin{array}{l}\text { Section 1: } \\
\text { Autocratic } \\
\text { Leadership Style } \\
\text { (ALS)- }\end{array}$ & 1 & 0.626 & 0.61 & 0.417 & 0.823 & 0.356 \\
\hline & $\begin{array}{l}\text { Section 2: } \\
\text { Democratic } \\
\text { Leadership Style } \\
\text { (DLS)- }\end{array}$ & 0.626 & 1 & 0.449 & 0.591 & 0.695 & 0.811 \\
\hline & $\begin{array}{l}\text { Section 3: } \\
\text { Laissez-faire } \\
\text { Leadership Style } \\
\text { (LFLS)- }\end{array}$ & 0.61 & 0.449 & 1 & 0.419 & 0.407 & 0.363 \\
\hline & $\begin{array}{l}\text { Section 4: } \\
\text { Situational } \\
\text { Leadership Style } \\
\text { (SLS)- }\end{array}$ & 0.417 & 0.591 & 0.419 & 1 & 0.404 & 0.537 \\
\hline & $\begin{array}{l}\text { Section 5: } \\
\text { Transformational } \\
\text { Leadership Style } \\
\text { (TLS)- }\end{array}$ & 0.823 & 0.695 & 0.407 & 0.404 & 1 & 0.44 \\
\hline & $\begin{array}{l}\text { Section 6: } \\
\text { Charismatic } \\
\text { Leadership Style } \\
\text { (CLS)- }\end{array}$ & 0.356 & 0.811 & 0.363 & 0.537 & 0.44 & 1 \\
\hline
\end{tabular}

The correlation analysis results indicate that the variables are not highly correlated, implying that they can be used in the regression analysis. As a result, the author performed a regression analysis to understand better the relationship between various leadership styles and employee motivation.

\subsection{Regression}

The regression analysis has been made to understand the relationship between different leadership styles and employee motivation. Here, the following regression model has been used.

$X($ Dependent Variable $)=Y($ Independent Variables $)$

Or Employee Motivation = Leadership Styles

Or Employee Motivation $($ EMTV) $=\{$ Autocratic Leadership Style (ALS) + Democratic Leadership Style (DLS) + Laissez-faire Leadership Style (LFLS) + Situational Leadership Style (SLS) + Transformational Leadership Style (TLS) + Charismatic Leadership Style (CLS)\}

The summary of the findings from the regression analysis is shown below: 
Table 5: Regression Summary and ANOVA

\begin{tabular}{|c|c|c|c|c|}
\hline \multicolumn{5}{|c|}{ Model Summary } \\
\hline Model & $\mathrm{R}$ & R Square & Adjusted R Square & $\begin{array}{c}\text { Std. Error of the } \\
\text { Estimate }\end{array}$ \\
\hline 1 & $918^{a}$ & 842 & 832 & 41794 \\
\hline \multicolumn{5}{|c|}{$\begin{array}{l}\text { a. Predictors: (Constant), Section 6: Charismatic Leadership Style (CLS)_ Section 1: Autocratic } \\
\text { Leadership Style (ALS)- , Section 4: Situational Leadership Style (SLS)- , Section 3: Laissez-faire } \\
\text { Leadership Style (LFLS)-, Section 5: Transformational Leadership Style (TLS)-, Section 2: } \\
\text { Democratic Leadership Style (DLS)- }\end{array}$} \\
\hline
\end{tabular}

\begin{tabular}{|c|c|c|c|c|c|c|}
\hline \multicolumn{7}{|c|}{ ANOVAa } \\
\hline \multicolumn{2}{|c|}{ Model } & $\begin{array}{l}\text { Sum of } \\
\text { Squares }\end{array}$ & df & Mean Square & $\mathrm{F}$ & Sig. \\
\hline \multirow[t]{3}{*}{1} & Reqression & 86.537 & 6 & 14.423 & 82.570 & $\mathrm{OOOO}^{\mathrm{b}}$ \\
\hline & Residual & 16.245 & 93 & 175 & & \\
\hline & Total & 102.782 & 99 & & & \\
\hline \multicolumn{7}{|c|}{ a. Dependent Variable: Section 7: Emplovee Motivation (EMTV)- } \\
\hline \multicolumn{7}{|c|}{$\begin{array}{l}\text { b. Predictors: (Constant), Section 6: Charismatic Leadership Style (CLS)_ Section 1: Autocratic } \\
\text { Leadership Style (ALS)- Section 4: Situational Leadership Style (SLS)-, Section 3: Laissez-faire } \\
\text { Leadership Style (LFLS)- Section 5: Transformational Leadership Style (TLS)-, Section 2: } \\
\text { Democratic Leadership Style (DLS)- }\end{array}$} \\
\hline
\end{tabular}

According to the analysis results, the value of $\mathrm{R}$ square is 0.842 , indicating a positive relationship between the dependent and independent variables. A one-unit change in the independent variables can result in a 0.842-unit change in the dependent variable. As a result, it was discovered that there is a strong link between various leadership styles and employee motivation.

Table 6: Coefficients of the variables

\begin{tabular}{|c|c|c|c|c|c|c|}
\hline \multicolumn{7}{|c|}{ Coefficients } \\
\hline \multirow{2}{*}{\multicolumn{2}{|c|}{ Model }} & \multicolumn{2}{|c|}{$\begin{array}{l}\text { Unstandardised } \\
\text { Coefficients }\end{array}$} & \multirow{2}{*}{$\begin{array}{l}\text { Standardised } \\
\text { Coefficients } \\
\text { Beta }\end{array}$} & \multirow[t]{2}{*}{$\mathrm{t}$} & \multirow[t]{2}{*}{ Sig. } \\
\hline & & $\mathrm{B}$ & Std. Error & & & \\
\hline \multirow[t]{7}{*}{1} & (Constant) & .026 & .180 & & .146 & .884 \\
\hline & $\begin{array}{l}\text { Section 1: Autocratic } \\
\text { Leadership Style (ALS)- }\end{array}$ & -.071 & .163 & -.071 & -.437 & .663 \\
\hline & $\begin{array}{l}\text { Section 2: Democratic } \\
\text { Leadership Style (DLS)- }\end{array}$ & -.386 & .167 & -.400 & -2.317 & .023 \\
\hline & $\begin{array}{l}\text { Section 3: Laissez-faire } \\
\text { Leadership Style (LFLS)- }\end{array}$ & .436 & .115 & .410 & 3.787 & .000 \\
\hline & $\begin{array}{l}\text { Section 4: Situational } \\
\text { Leadership Style (SLS)- }\end{array}$ & .442 & .132 & .474 & 3.356 & .001 \\
\hline & $\begin{array}{l}\text { Section 5: Transformational } \\
\text { Leadership Style (TLS)- }\end{array}$ & .419 & .155 & .409 & 2.712 & .008 \\
\hline & $\begin{array}{l}\text { Section 6: Charismatic } \\
\text { Leadership Style (CLS)- }\end{array}$ & .150 & .095 & .149 & 1.582 & .117 \\
\hline
\end{tabular}

Finally, the coefficients of the variables have been determined to determine the study's significant variables. The researcher discovered that Democratic Leadership Style (DLS), Laissez-faire Leadership Style (LFLS), Situational Leadership Style (SLS), Transformational Leadership Style (TLS), and Charismatic Leadership Style (CLS) are the most significant variables among the six variables studied: Autocratic Leadership Style (ALS), Democratic Leadership Style (DLS), Laissez-faire Leadership Style (LFLS), Situational Leadership Style (SLS), Transformational Leadership Style (TLS), and Charismatic Leadership Style (CLS). Again, the study's less significant variables were Autocratic Leadership Style (ALS) and Charismatic Leadership Style (CLS). 


\section{Discussion}

\subsection{Leadership Styles}

The result is consistent with Jayasingam and Cheng (2009), who stated that this kind of leader controls all actions and choices while restricting personnel's ability to innovate. As a result, this leader attempts to limit employee performance. Employees were given a little opportunity to offer suggestions because they were given a small chance (Amanchukwu et al., 2015). An autocratic leader usually makes choices based on their views and opinions, which seldom include input from followers, and all these leaders maintain complete control over their employees (Zareen et al., 2015).

As a result, the researchers discovered a link between transformative leadership and employee motivation. A favourable connection has also been found in certain areas between transactional leadership style and employee motivation. In their stated views, respondents do not see much of a distinction between transformative and traditional leadership practices. The transactional portion of the conducted interview, on the other hand, followed a distinct pattern. The transactional leadership levels are less linked to each other, indicating that transformational leadership is more successful than transactional leadership at drawing in workers and creating opportunities for motivation. This is comparable to the findings of Jayasingam and Cheng (2009), who discovered that autocratic power had a detrimental impact on employee performance. Puni et al. (2014) and Akor (2014) study back up this claim.

Autocratic leadership, from the other side, has a negative effect on staff motivation. This implies that under an authoritarian leadership style, workers are not motivated. Employees are not affected by charismatic or laissez-faire leadership styles, according to our findings from the interview. It has also been discovered that the situational leadership style does not affect the motivation of any employee. We gathered from the interviews that none of the employees had any experience with these three leadership styles. The findings and consequences of this study provide suggestions for improving a manager's leadership abilities to improve employee motivation.

According to Ojokuku, et al., (2012) this finding is correct. According to the research, under this kind of leadership style, workers are encouraged to believe that the company is there for them and are given more responsibility with very little supervision, which leads to increased organisational efficiency as per Iqbal et al. (2015) as well as Bhatti et al. (2012) study have both given their approval. This kind of leadership promotes innovation, teamwork, and employees are often involved in tasks that improve performance (Verba, 2015). Such leaders don't offer recommendations, but they question other people's views (Iqbal et al., 2015). This leadership encourages all organisation members to participate in the ultimate decision-making process and in all other steps necessary to achieve their goals (Trivisonno and Barling, 2016). This leader's personality is linked to dissatisfaction, a lack of productivity, and creativity (Limsila and Ogunlana, 2008). Morreale (2002) claims that the manager fails to lead the team and fulfil their leadership responsibilities. Leaders with this manner maintain a hands-off approach, participating in decision-making only rarely and providing no advice or direction. This conclusion differs from Chaudhry and Javed's (2012) findings, which show a link between laissez-faire leadership style and employee motivation. Nuhu (2010) and Sougui et al. (2016) studies have backed up this assertion.

\subsection{Effect of Leadership Styles on Employee Motivation}

According to the study's findings, there is a strong positive connection between transformational leadership and employee performance and staff motivation. This same transactional leadership style of the leaders seems to have a significant effect on the degree of motivation of workers, as it relates to the connection between transactional leadership style and employee motivation; it was apparent that there is a tangible tie between the two. The authoritarian style of leadership has a negative effect on staff motivation. The findings of the studies showed that authoritarian leadership does not have a positive impact on employee motivation. One of the study's key findings is that leaders should avoid conduct that resembles authoritarian leadership. Even though this research was unable to find any substantial evidence to indicate whether any leadership styles are a complete waste of time or outright unfavourable, it can be stated without a shadow of a doubt that certain leadership styles are much more effective than others. With careful regard to our previous remark that no leadership style is flawless or all-sufficient, this viewpoint constitutes an essential element of our contribution. Furthermore, businesses should work to improve their understanding of how their leadership style affects their workers. Choosing the style that 
best fits the organisation's objectives and the needs/desires of employees would be a welcoming policy that will boost employee productivity and motivation.

\section{Conclusion}

It may be stated that democratic leadership is the most often used leadership style among direct supervisors in the automotive sector. Furthermore, a modest degree of laissez-faire leadership is used. Autocratic leadership styles boost employee motivation. The results indicate that employee performance improves when an autocratic style is used, although this is statistically insignificant. Democratic leadership is a crucial type of leadership that promotes job execution and staff success. Employees preferred a democratic leadership style placed above a white transactional autocratic leadership as well as a laissez-faire leadership style. As a result, the democratic leadership style received the highest average score of something like the employee motivation measurement over transactional autocratic leadership and laissez-faire leadership style. As a result, it can be stated that increasing democratic leadership style leads to higher employee motivation. Employee performance benefits from a laissez-faire leadership style. Employee motivation in the automotive sector has increased when a laissez-faire style of leadership is used, although this is not statically important.

Employees are usually expected to be loyal to their bosses. Employees' expectations of their leaders, and the preferred leadership styles, were investigated in this research. The study's results and other helpful material in this work will assist in the creation of strategies and the achievement of goals via the development and adoption of a good leadership style. As a result, leaders and managers should be aware of the significance of transformational leadership and strive to demonstrate it in their daily activities. Transactional leadership is indeed a powerful form of leadership. It showed a somewhat favourable relationship with employee motivation at work. Loyalty to the boss and internalisation of supervisor's values were slightly correlated with individualised consideration and active management-by-exception. It suggests that a fair compensation package with appropriate perks is critical for employee-leader interactions and employee motivation. Managers should work with workers to develop an inclusive and equitable incentive system. Expectations should be defined, and if objectives are met, preparations should be made for employees to be acknowledged in return for their efforts. Employees would be more willing to take on additional tasks if they knew their efforts would be rewarded somehow. When mistakes have been made at business, leaders must pay close attention to the faults and the standards that must be met, maintain a note of the errors, and take corrective action as quickly as possible.

\section{References}

Achua, C.F. and Lussier, R.N., (2013). Effective leadership. South-Western Cengage Learning.

Adams, J; Raeside, R and Khan, HA, (2014), Research Methods for Business and social science Students, 2nd and, Sage

Publications Pvt. Ltd., New Delhi.

Arbnor, I and Bjerke, B 2009, Methodology for creating Business Knowledge, 3rd and. London: sage publications.

Badaracco, J. (2002) Leading Quietly - an Unorthodox Guide to Doing the Right Thing. Harvard Business School Press.

Bhatti, N. et al., (2012). The Impact of Autocratic and Democratic Leadership Style. International Business Research, 5(2), pp. 192-201.

Bleich, E. (2011). What is islamophobia and how much is there? Theorising and measuring an emerging comparative concept. American Behavioral Scientist, 55(12), 1581-1600.

Blanchard, O.J (2008). THE STATE OF MACRO. Cambridge: NBER publications.

Bolden, R. (2004). What is Leadership? 1st ed. Exeter: University of Exeter. 59

Bryman, A. and Bell, E., 2011. Business research methods. Cambridge: Oxford University Press.

Burns, A. (2010). Doing Action Research in Language Teaching: A Guide for Practitioners. NY: Routledge.

Chaudhury, A. and Javed, H. (2012). Impact of Transactional and Laissez-Faire Leadership Style on Motivation. International Journal of Business and social science, 03(07), pp.259-264.

Chi, Lan, and Dorjgotov, (2012). The moderating effect of transformation leadership on knowledge management and organisational effectiveness.

Collis, J. and Hussey, R., 2014. Business research: A practical guide for undergraduate and postgraduate students. 4th edition. New York: Palgrave Macmillan International Higher Education.

Corbin, J and Strauss, 2008, Basics of Qualitative Research: Techniques and Procedures for Developing Grounded Theory, 3rd ed, SAGE Publications.

Creswell, J. (2014). Research Design. 4th ed. London: SAGE Publication. 
De Cremer, D. (2004). The influence of accuracy as a function of leader's bias: The role of trustworthiness in the psychology of procedural justice. Personality and Social Psychology Bulletin, 30, 293 - 304.

Dhaka Tribune. (2018). Experts on banking industry seminar: Lack of efficient leadership caused mounting NPLs, scams, corporate frauds in the banking sector. [online] Available at:

https://www.dhakatribune.com/business/2018/10/22/experts-on-banking-60

Dyczkowska, J. and Dyczkowski, T. (2018). Democratic or Autocratic Leadership Style? Participative Management and its Links to rewarding Strategies and Job Satisfaction in SMEs. Athens Journal of Business and Economics, 04(02), pp.193-2017.

Egwunyenga, E.J. (2010). Essentials of school administration. Benin City: Justice- Jeco Publishers.

Faeth, M.A., 2004. Power, authority, and influence: A comparative study of the behavioural influence tactics used by lay and ordained leaders in the Episcopal Church (Doctoral dissertation, Virginia Tech).

Fiedler, F.E. (1967). A Theory of Leadership Effectiveness. Mc Graw-Hill Book Company, New York.

Gosling, J. and Mintzberg, H. (2003) The five minds of a manager. Harvard Business Review, 81, 54-63. 61

Gosling, J. and Murphy, A., (2004). Leading continuity. Working Paper: Centre for Leadership Studies, University of Exeter.

Grint, K. (2004) what is Leadership? From Hydra to Hybrid. Working paper, Saïd Business School and Templeton College, Oxford University

Hammond, J.L., 2019. Gladstone and the Irish nation. Routledge.

Haque, M., Haque, M. and Islam, M. (2014). ASA University Review. Motivational Theories - A Critical Analysis, 08(01), pp.62-68.

Herzberg, Frederick (1966). Work and the Nature of Man. Cleveland: World Publishing

Hinkin, T. and Schriesheim, C. (2008). A theoretical and empirical examination of the transactional and nonleadership dimensions of the Multifactor Leadership Questionnaire (MLQ). The Leadership Quarterly, 19(5), pp.501-513.

Igbaekemen, G. O., (2015). Impact of Leadership Style on Organization Performance: A Strategic Literature Review. Public Policy and Administration Research, 4(9), pp. 126-136.

Irny, S.I. and Rose, A.A., (2005). Designing a Strategic Information Systems Planning Methodology for Malaysian Institutes of Higher Learning (isp-ipta), Issues in Information System, Volume VI, No. 1.

Judge, T.A. and Piccolo, R.F., (2004). Transformational and transactional leadership: a meta-analytic test of their relative validity. Journal of applied psychology, 89(5), p.755.

Keup, J., Walker, A., Astin. H. and Lindholm, J. ed., (2001). Organizational Culture and Institutional Transformation. 1st ed. Washington: ERIC Clearinghouse on Higher Education.

Klenke, K; Wallace, JR, and Martin S, (2015), Qualitative Research in the study of leadership, 2nd eds. Bingley: Emerald Group Publishing Limited.

Latham, G.P., (2007). A speculative perspective on the transfer of behavioural science findings to the workplace: "The times they area-changing'". Academy of Management Journal, 50(5), pp.1027-1032.

Lewis, R., Feilder, E. and Godfree, K. (2017). Developing managers to manage sustainable employee engagement, health, and well-being. Developing managers to manage sustainable employee engagement, health and well-being, pp.228.

Liya G. Mariam (2018). Effect of leadership style on employee's performance at wegagen bank's c.

MacGregor Bums, (2003). Transformational leadership is the pursuit of happiness.

Maslow, A. H. (1954). Motivation and personality. New York: Harper and Row.

Markwell, J. (2004). The human side of science education: Using McGregor's theory Y as a framework for improving student motivation. Biochemistry and Molecular Biology Education, 32(5), pp.323-325.

McGrath, R.G., and MacMillan, I.C. (2000) The entrepreneurial mindset: Strategies for continuously creating opportunity in an age of uncertainty (Vol. 284). Harvard Business Press.

Michael. A. (2010). Leadership style and organisational impact.

Mullins, A. (2007). Management and Organisational Behavior. 8th Edition. England: Pearson Education Limited.

Musinguzi C, Namale L, Rutebemberwa E, Dahal A, Nahirya-Ntege P, Kekitiinwa A (2018) The relationship between leadership

style and health worker motivation, job satisfaction and teamwork in Ugand, Journal of Healthcare Leadership, April 2018

Volume, https://doi.org/10.2147/JHL.S147885

Naile, I. and Selesho, J. (2014). The Role of Leadership in Employee Motivation. Mediterranean Journal of Social Sciences, 5 (3), $175-182$.

Northouse, PG (2004) Leadership: Theory and Practice (3rd Edition). London: Sage Publications Ltd.

Nikezic, S., Puric, S. and Puric, J., (2012). Transactional and transformational leadership: Development through changes. International Journal for Quality Research, 6(3), pp.285-296.

Obiruwu A. (2011). Leadership styles and their effect on organisational performance 
Ojokuku, R., Odetayo, T. and Sajuyigbe, A., (2012). Impact of Leadership Style on Organisational Performance: A Case Study of Nigerian Banks. American Journal of Business Management, 1(4), pp. 202-207.

Pellegrini E. K., Scandura T. A. (2008). Paternalistic leadership: a review and agenda for future research. J. Manage. 34 566-593.

Sougui, A.O., Bon, A.T., Mahamat, M.A. and Hassan, H.M.H., 2016. The Impact of Leadership on Employee Motivation in Malaysian Telecommunication Sector. Galore International Journal of Applied Sciences and Humanities, 1(1).

Qureshi, M., Zaman, K. and Bhatti, M. (2011). The impact of culture and gender on leadership behaviour: Higher education and management perspective. Management Science Letters, 01(04), pp.531-540.

Ramlall, S., (2004). A review of employee motivation theories and their implications for employee retention within organisations. Journal of American Academy of Business, 5(1/2), pp.52-63.

Robbins, S. and Judge, T. (2013). Organisational behaviour. 15th ed. New Jersey: Pearson Education, Inc.

Saunders, M., Lewis, P. and Thornhill, A., (2009). Research methods for business students. Essex. Financial Times/Prentice Hall. 64

Schaffer, B. (2008). Leadership and motivation. Supervision, 69(2), pp.6-9.

Sekaran, U., (2003). Research methods for business: A skill Building Approach. 4thedition. John Wiley and Sons: New York.

Sekaran, U. and Bougie, R., (2010). Theoretical framework in the theoretical framework and hypothesis development. Research methods for business: A skill-building approach, 80 .

Shahjalal Islami Bank Limited Annual Report. (2017). 1st ed. Dhaka.

Speer, S. and Stroke, E., (2014). Ethics in action: consent-gaming interactions and implications for research practice. The British Journal of social psychology/the British psychological society (online), 53 (1), 54-73.

Skogstad, A., Nielsen, M. B., and Einarsen, S. (2017). Destructive forms of leadership and their relationships with employee well-being. In E. K. Kelloway, K. Nielsen, and J. K. Dimoff (Eds.), Leading to occupational health and safety: How leadership behaviours impact organisational safety and well-being (pp. 163-195). Chichester, UK: Wiley.

Speer, S. and Stokoe, E., (2014). Ethics in action: consent-gaining interactions and implications for research practice. The British Journal of Social Psychology / The British Psychological Society [online], 53 (1), 54-73.

Sy, T., Horton, C. and Riggio, R. (2018). The Leadership Quarterly. Charismatic leadership: Eliciting and channelling follower emotions, 29(1), pp.58-69.

Wang, F.J., Chich-Jen, S. and Mei-Ling, T., (2010). Effect of leadership style on organisational performance as viewed from human resource management strategy. African Journal of Business Management, 4(18), pp.3924-3936.

Wilmot, A., (2005). Designing sampling strategies for qualitative social research: with reference to the Office for National Statistics' Qualitative Respondent Register. SURVEY METHODOLOGY BULLETIN-OFFICE FOR NATIONAL STATISTICS-, 56, p.53.

Wong, S. and Giessner, S. (2016). The Thin Line Between Empowering and Laissez-Faire Leadership: An ExpectancyMatch Perspective. Journal of Management, 44(2), pp.757-783. 66

Yin, RK, (2014), Case Study Research - Design and Methods, 5th end, SAGE Publications Ltd, London.

Yukl, G. (2001). Leadership in organisations. Upper Saddle River, NJ: Prentice-Hal.

Yukl, G. (2014). Leadership in Organisations (7th Suppl.), Noida: Pearson India Education Services Pvt Ltd.

Yun, S., Cox, J. and Sims Jr, H. (2006). The forgotten follower is a contingency model of leadership and follower selfleadership. Managerial Psychology, 21(04), pp.374-388.

Zenger, John J., and Joseph Folkman (2002). The extraordinary leader: Turning good managers into great leaders. New York, New York: McGraw Hill. 